\title{
Impact of Urbanization on Agricultural Land in Makurdi Local Government Area of Benue State, Nigeria
}

\author{
Dr. Terwase Shabu Sussan Fate Mfanyo Keziah Ukula \\ Department of Geography, Benue State University, Makurdi
}

\begin{abstract}
This study assessed the Impact of Urbanization on Agricultural Land in Makurdi Local Government Area of Benue State. The data collected were population figures and land use for three Epoch (1997, 2007 and 2017). The satellite images were sourced from the National Center for Remote Sensing and Geographic Information System, Jos. In the analysis, cross change detection analysis and overlay analysis using ArcGIS 9.0 was performed to detect where land-use change has occurred and which type of land use agricultural land has transformed too. The GIS analysis revealed that there is an increase in settlement and a decrease in Agricultural land from 1997 - 2017. It also revealed that 99.51 ha of agricultural land use has been converted to settlement between 1997 and 2017. The results reveal that urbanization has significant effects on Agricultural Land in the study area and these effects include; decreasing agricultural land, decreasing agricultural activities and decrease in farm size. If the growth in the population of Makurdi LGA continues unchecked, agricultural land will be significantly depleted in the future. The study recommended that there should be effective law and policy to control population growth sustainably to minimize the negative impact of urbanization in the study area. Also, urban agriculture should be encouraged to sustain the food supply in urban areas.
\end{abstract}

DOI: $10.7176 / \mathrm{JAAS} / 70-04$

Publication date: January $31^{\text {st }} 2021$

\section{INTRODUCTION}

Urbanization is the process of evolution of urban settlements. The increase in the population of the people that live in cities can give rise to urban expansion. This usually is as a result of the net movement of people from rural to urban areas or natural increase (the excess of birth over death). The movement of people from rural to urban areas in search of better livelihood can lead to the expansion of urban areas and an increase in social and economic activities. Urban growth is indicated by an increase in the population of people living in these areas. However, the definition of what qualifies as an urban centre differs from one country to another depending on the criteria used. Urbanization is not a modern phenomenon: it has been occurring since about 5000 B.C. (Sjoberg, 1960). The level of urbanization, measured by the proportion of the urban population has been increasing over the years (Fellmann, Getis and Getis, 1997). The urban population has been growing more rapidly than the rural population worldwide, particularly in developing countries (Lambin et al, 2003). There are three major concerns over the continuing farmland loss due to urbanization (Oueslati, Sulenie and $\mathrm{Wu}, 2014$ ). First, the conversion of the most fertile farmland to urban development reduces agricultural productivity, which decreases food supply in the short run and threatens food security in the long run. Second, farmland development reduces amenities and quality of life in rural communities. Third, farmland loss may have a detrimental effect on agricultural land use. As urban development increases, land-use conflicts are likely to be more severe at the urban fringe. However, the role of agriculture and urbanization has always been at the heart of the debate on sustainable land use patterns in a modern economy.

One of the several anthropogenic activities that impact on land use/land cover is urbanization. The urban area where human beings live in is the symbol of human civilization and it is an important place for humans to do their economic and social activities. Urbanization is a significant characteristic of humans' modern lives. For a city, the level of urbanization can be used to estimate the level of economic, social, scientific and technological development. Meanwhile, it is very important to monitor the level of management and organization of the city. The result of such changes in the impacts of the urban area on the natural landscape, river morphology, drainage system and land use/land cover of the area, increasing the frequency of water-induced hazards (Manandhar, 2010). Though human beings have been modifying land to obtain food, shelter and other essentials of life for thousands of years, current rates, extents and intensities of such modifications are far greater than ever in history. This has driven unprecedented change in the ecosystem and environmental processes at local and regional scales.

The effect is that there is high pressure on and the struggle for available natural resources. The land is the most important natural resources on which all activities are based. Land use unlike geology is seasonally dynamic and indeed is more changing. The increase in population and human activities are increasing the demand on the limited land resources for agriculture, forest, pasture, urban and industrial land uses.

Generally, towns and cities in Nigeria are noted to be growing very rapidly. The national average urban growth rate is about 10\% per annum (Oguntoyinbo, 1981; Adedeji and Rowland, 1973). The Nigerian cities are growing faster than their European counterparts did at the peak of their growth (NITP, 2014). Rapid urban growth 
means an increasing demand for land or housing and other urban uses. Population increase and the corresponding urbanization in the country are responsible for increased demand for land that has culminated to change in land use. Land-use change has occurred among other reasons at the expense of agricultural activities.

In Benue, over $70 \%$ of the population is involved in agriculture as a major source of employment to the populace. Depriving the sector of land therefore brings an increase in the unemployment rate. In the urban areas, the cumulative effects of succession and dominance factors have made land increasingly scarce for rural and periurban farmers. Rapid urbanization has adversely affected development efforts in many cities. One of these is changes in land use subsequently leading to decreased agricultural land in favour of the provision of residential accommodation in most urban settlements. This is reflected in the form of dormitory and satellite towns that are being developed in the urban peripheries which were agricultural lands in the urban setting. The key challenge of the urbanization process is the rapid conversion of a large amount of prime agricultural land to urban land use (mostly residential construction), in the urban periphery. The effect is the unavailability of prime agricultural lands. The consequence is low agricultural productivity, low standard of living and food insecurity. Urbanization in Makurdi has come with serious loss of arable land, degradation of the ecosystem as well as social and environmental changes to the urban population. The current urbanization process in Makurdi is an indication of a process that needs considerable attention not only as a basis for the transformation of societies but also for sustainable development (Muhammed, Sabiu, Khalil, 2015). As cities grow and expand, it is expected that economic growth and development will progress and act as a driver for social transformation and improvement of not only urban areas but the greater rural hinterland served by the urbanized region (Shabu, 2010; Sati, Deng, Zhang, Wan and Song, 2017). However, this has not been the case as in Makurdi. Through its increased urbanization, the city has instead experienced increased and persistent urban poverty; poor environmental sanitation, food crises/shortages, housing, transportation and pollution problems. Moreover, areas of recent urban expansion and settlements of the urban poor are the most vulnerable to these challenges.

Agricultural land use may be referred to as how land and its resources are employed for agricultural purpose/development. Land use is very dynamic and has to be monitored at regular intervals to achieve sustainable environmental and agricultural development. The population is a very important factor or agent of change in land use in an area. For instance, as population increases in an area, there is a proportional increase in the expansion of settlements, commercial and industrial activities, thus engendering conversion of cropland and forest land to settlement as it is the case in Makurdi LGA of Benue State. The importance of agriculture to the people of Benue State in general and the people of Makurdi LGA of Benue State, in particular, cannot be overemphasized. However, in recent times it does seem like agricultural activities and agricultural land use in the area are on the decrease due to the increase in population and urban growth. Despite the threat pose on food security by urbanization in Benue State in general and Makurdi Metropolis and its environs in particular, it is noteworthy that there seems to be little or no systematic and general knowledge about how different rates and levels of urbanization affect agricultural land use in the area and its environs. More so, the relationship between urbanization and agricultural land use in the area seems to have received a limited empirical assessment, particularly in the context of developing countries. It is against these backdrops that this study seeks to evaluate the impact of urbanization on agricultural land use in Makurdi LGA of Benue State and suggest ways of sustainable agriculture in the area.

\section{MATERIALS AND METHOD \\ The Study Area}

Makurdi Local Government Area lies between lat. $70001 \mathrm{~N}$ and $70451 \mathrm{~N}$ and long 80001 and $80321 \mathrm{E}$ in the northeastern part of Benue state (Figure 1). It is situated within a physiographic zone called the Benue trough with a mean elevation of 92 meters above sea level. Makurdi is bounded by Gwer West Local Government Area to the west, Gwer East Local Government Area to the south, Guma to the North East and Doma to the North West. Politically, it falls within the Middle Belt region of Nigeria and has a radius of 16 kilometres from its centre. It is the capital of Benue state and headquarters of Makurdi Local Government Area. It serves as a major link between the Northern and Southern parts of Nigeria. The town has several drainage channels. These channels include river Benue, which bisects the town into South and north banks, and its tributaries including Urudu, Demepe, Kereke and $\mathrm{Mu}$ and the smaller ones include Idye and Kpege.

According to 1991 and 2006 censuses, the population of Makurdi were 239, 889 and 297 398. Projected at the growth rate of $0.03 \%,[\mathrm{Pt}=239,889(1+0.03) 26=517,342]$, Makurdi LGA has a total population of 517,342 persons including male and female in 2017 . Makudi has a fast-growing population with a population density of 323 persons per square kilometre, about $8.14 \%$ of this entire population represent the population of the state (Denga, 1995). The 2006 figure was 297398 including male and female, the male figure was 157, 295 while that of females was 140,103 respectively. The population is made up of the Tiv speaking population as the majority, followed by the Idoma and Igede speaking population with other ethnic groups that are relatively few. 


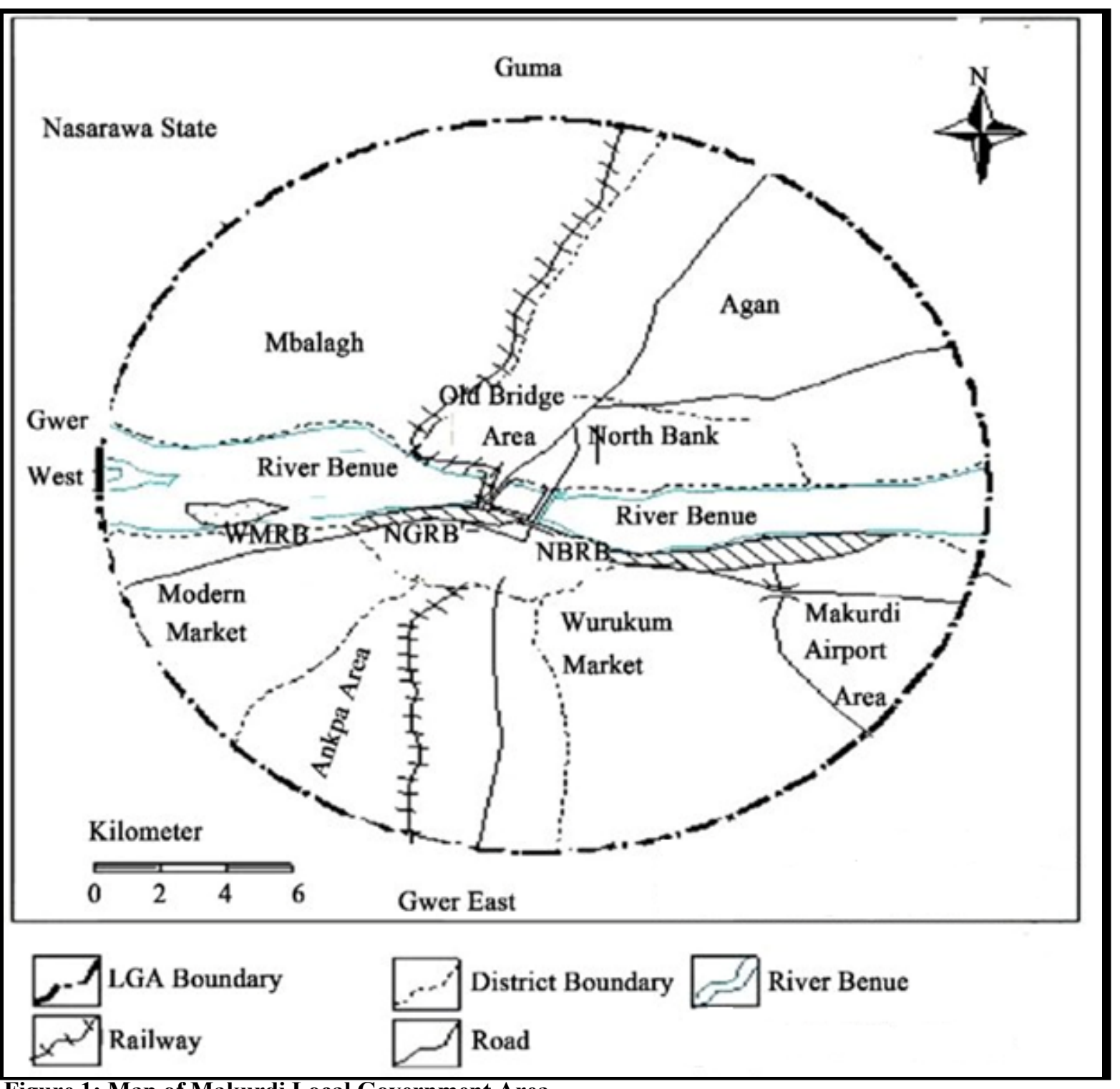

Figure 1: Map of Makurdi Local Government Area

Source: Ministry of Lands and Survey, Makurdi

Although the settlement pattern is a well-planned settlement with street layouts and plots, however, the settlement keeps expanding due to urban growth, while agricultural land keeps shrinking proportionally. The settlement pattern in Makurdi is described as a nucleated type within the urban districts such as high-level, Wadata, Wurukum, Low-level, Kanshio, North bank, Madikpo, new government reserved area (new GRA), Federal housing and Logo (Denga 1995) while places at the periphery can be seen as dispersed such as Agan, Fiidi, Mbalagh and Bar ward.

The dominant Land use in Makurdi and its environs are settlement, agriculture, industrial, commercial and infrastructure development among others. Small and large scale industries abound, tourism and recreational areas, telecommunication and transportation. Many secondary schools and primary schools are also found in the area. In terms of higher education, there are two major universities, namely; the Benue State University (BSU) and the Federal University of Agriculture (FUAM).

\section{Method}

Assessing the impact of Urbanization on Agricultural Land in Makurdi LGA of Benue State require information on the land use and land cover type for at least two decades, in addition to this, views and observations of the inhabitants are also required. Therefore, the required data for this study include: land use and landcover attribute from the satellite image of the study area for three Epoch (1997, 2007 and 2017) were generated. These images were sourced from the National Center for Remote Sensing and Geographic Information System in Jos, Plateau State. Size of agricultural land, population growth, economic growth, the standard of living, environmental pressure, and industrialization were collected. Also, other variables such as agricultural intensification, population 
figure for 1997 - 2017 from the National Population Commission (NPC).

The population for this study comprises of the entire inhabitant of the study area. The population of the study area was projected 517,342 people in 2017 using an annual growth rate of $0.03 \%$. Areas of interest will be; Nyiman and its environs, New GRA and its environs, Welfare quarters and its environs, Naka Road (industrial layout) and its environs, and owner's occupier (international market areas) and its environs among others. These areas are of interest because observation has shown that rapid expansion of settlements and industrial activities in recent time in these areas may not be unconnected with urban growth.

The Landsat imageries were processed using "image classification", change detection" and "change analysis". In the GIS analysis, cross-analysis change detection result and overlay analysis was performed using ArcGIS 9.0 to detect "where another land-use change has occurred and which type of land use has agricultural land use transformed into.

\section{RESULTS AND DISCUSSION}

Rate of urbanization in Makurdi LGA of Benue State

Population trend in the study area between 1997 and 2007, and 2017 and a forecast from 2017 to 2027 were also analyzed. The trend in population growth in the study area between 1997 and 2007, 2007 and 2017 and what it will be between 2017 and 2027 is presented in Table 1 .

Table 1: Population Trend between 1997 and 2027 in Makurdi

\begin{tabular}{|c|c|c|c|c|c|c|c|c|c|}
\hline \multicolumn{4}{|c|}{ Population } & \multirow{2}{*}{\multicolumn{2}{|c|}{$\begin{array}{l}\text { Changes } \\
\text { between } \\
1997 \text { and } 2007 \\
\end{array}$}} & \multirow{2}{*}{\multicolumn{2}{|c|}{$\begin{array}{l}\text { Changes } \\
\text { between } \\
2007 \text { and } 2017 \\
\end{array}$}} & \multirow{2}{*}{\multicolumn{2}{|c|}{$\begin{array}{l}\text { Forecast Changes } \\
\text { between } \\
2017 \text { and } 2027 \\
\end{array}$}} \\
\hline 1997 & 2007 & 2017 & $\begin{array}{l}2027 \\
\text { (forecast) }\end{array}$ & & & & & & \\
\hline 286,440 & 384,951 & 517,342 & 695,264 & $\begin{array}{l}\text { Pop } \\
\text { change }\end{array}$ & $(\%)$ & $\begin{array}{l}\text { Pop } \\
\text { change }\end{array}$ & $(\%)$ & Pop change & $(\%)$ \\
\hline & & & & 98,511 & 34.39 & 138,391 & 45.21 & 177,922 & 62.11 \\
\hline
\end{tabular}

Source: National Population Commission (NPC, 2006)

Table 1 shows that Makurdi had a total population of 286,440 in 1997, a total of 384,951 people in 2007 and 517,342 people in 2017 and it is estimated to reach 695,264 in 2027 (see Figure. 2). The table also reveals the percentage of change (increase) in the population of the study area between 1997 and 2007, 2007 and 2017 and a forecast from 2017 to 2027. It is observed that there is an increase of $34.39 \%$ in a population of Makurdi between 1997 and 2007 and there is an increase of $45.21 \%$ in population between 2007 and 2017. Similarly, the forecast between 2017 and 2027 shows an increase of $62.11 \%$. It can be inferred that there is a steady increase in population in the study area between 1997 and 2007, 2007 and 2017 and the increase will rise higher between 2017 and 2027. This implies that the population of Makurdi increased by $80 \%$ within 20 years. All things being equal, will increase by $142 \%$ in 30 years.

These findings support the opinion of some early scholars, for example, (Angel et al., 2005; Adeboyejo and Abolade, 2007). Olima (2003) opined that the population growth rate in both urban and rural area is not commensurate with the quantity of land supply. The land is fixed in nature and so does not increase with increasing population growth. Expansion of cities affects the areas surrounding them (i.e., the suburbs) by altering the natural resource base and converting vegetal land cover to new uses, thus challenging the environment and dwellers' livelihoods. The unprecedented rate of urbanization and the sprawling pattern of development have resulted in the quick disappearance and/or total alteration of fertile agricultural lands in peri-urban areas. It was estimated that approximately 14 million hectares of land (approx. 475,000 ha/yr.) in developing countries would be converted into various land uses/development between 1990 and 2020 (Naab et al. 2013). Approximately 400,000 hectares of vegetative land cover has been lost (Adesina, 2005), with more expected to be lost due to various physical developmental projects in most urban settlements (Appiah, 2014; Dekolo and Olayinka, 2014; Mugish and Nyandwi, 2015). Such loss could be due to dormitory and satellite towns (Zasada, 2011) which result in the outward expansion of built-up areas beyond visible and invisible city borders into green areas mainly used for farming (Brennan, 1999; Kwasi, 2004; Oyesiku, 2010).

\section{Land use/Land cover Change in Study Area}

The changes in land cover/land use between 1997 and 2007 are presented in Table 2. The data shows the total area covered by each feature in hectares and their respective proportions in 1997 and 2007. The Table also reveals the percentage change of land cover types that occurs in the area between 1997 and 2007. A negative change indicates loss of land cover/land use type. 
Table 2: Changes in Land cover/land use pattern between 1997 and 2007 in Makurdi

\begin{tabular}{llllll}
\hline \multirow{2}{*}{ Features } & \multicolumn{2}{l}{ Total Area(Ha) } & \multicolumn{2}{c}{ Total Area (\%) } & $\begin{array}{l}\text { Change } \\
(\mathbf{\%})\end{array}$ \\
\cline { 2 - 5 } & $\mathbf{1 9 9 7}$ & $\mathbf{2 0 0 7}$ & $\mathbf{1 9 9 7}$ & $\mathbf{2 0 0 7}$ & -2.72 \\
\hline Forest & 36.43 & 13.98 & 4.41 & 1.69 & 8.41 \\
Agricultural Land & 163.88 & 233.23 & 19.86 & 28.27 & -9.73 \\
Grassland & 541.11 & 460.82 & 65.58 & 55.85 & 0.34 \\
Bareland & 2.28 & 4.50 & 0.2 & 0.54 & 3.67 \\
Settlement & 48.86 & 79.19 & 5.92 & 9.59 & -0.03 \\
Water body & 33.52 & 33.28 & 4.06 & 4.03 & \\
\hline
\end{tabular}

Source: GIS Analysis, 2019

The data revealed that forest, grassland and water body have negative changes of $-2.72 \%,-9.73 \%$ and $-0.03 \%$ between 1997 and 2007, while agricultural land, bare land and settlement have positive changes of $8.41 \%, 0.34 \%$ and $3.67 \%$. It can be deduced that there is an increase in settlement expansion and this may be due to the increasing population in the study area.

Table 3: Changes in Land cover/land use pattern between 2007 and 2017 in Makurdi

\begin{tabular}{|c|c|c|c|c|c|c|}
\hline \multirow[t]{2}{*}{ Features } & \multicolumn{2}{|c|}{ Total Area(Ha) } & \multicolumn{2}{|c|}{ Total Area (\%) } & \multirow{2}{*}{$\begin{array}{l}\text { Change } \\
(\%)\end{array}$} & \multirow[t]{2}{*}{ Period (Years) } \\
\hline & 2007 & 2017 & 2007 & 2017 & & \\
\hline Forest & 13.98 & 21.48 & 1.69 & 2.60 & 0.91 & 10 \\
\hline Agricultural Land & 233.23 & 176.72 & 28.27 & 21.42 & -6.85 & 10 \\
\hline Grassland & 460.82 & 478.59 & 55.85 & 58.01 & 2.16 & 10 \\
\hline Bareland & 4.50 & 1.66 & 0.54 & 2.01 & 1.47 & 10 \\
\hline Settlement & 79.19 & 114.01 & 9.59 & 13.81 & 4.22 & 10 \\
\hline Water body & 33.28 & 33.51 & 4.03 & 4.06 & 0.03 & 10 \\
\hline
\end{tabular}

Source: GIS Analysis, 2019

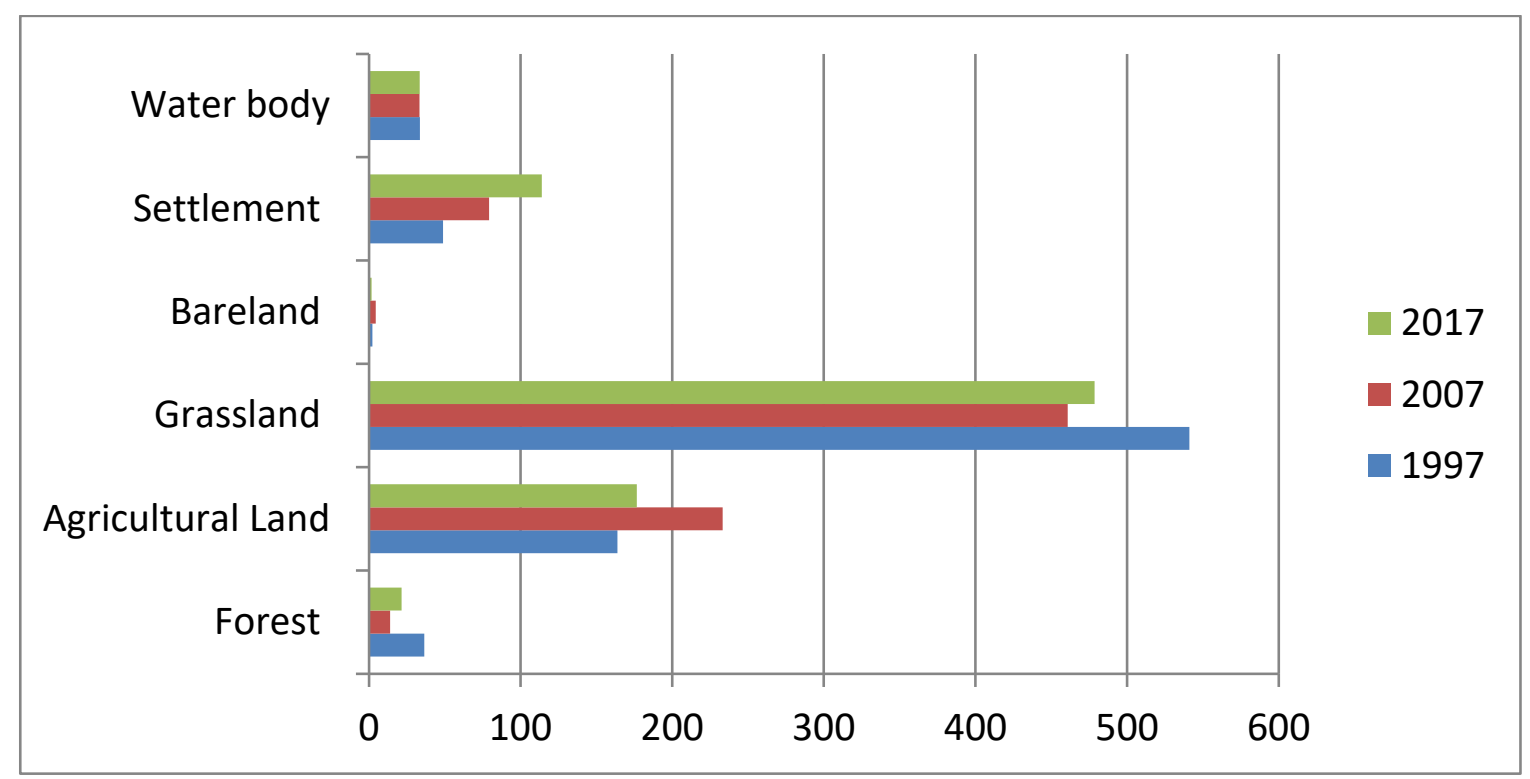

Figure 2: Areal Extent of Land Use/Land Cover in Makudi Source: GIS Analysis, 2019 


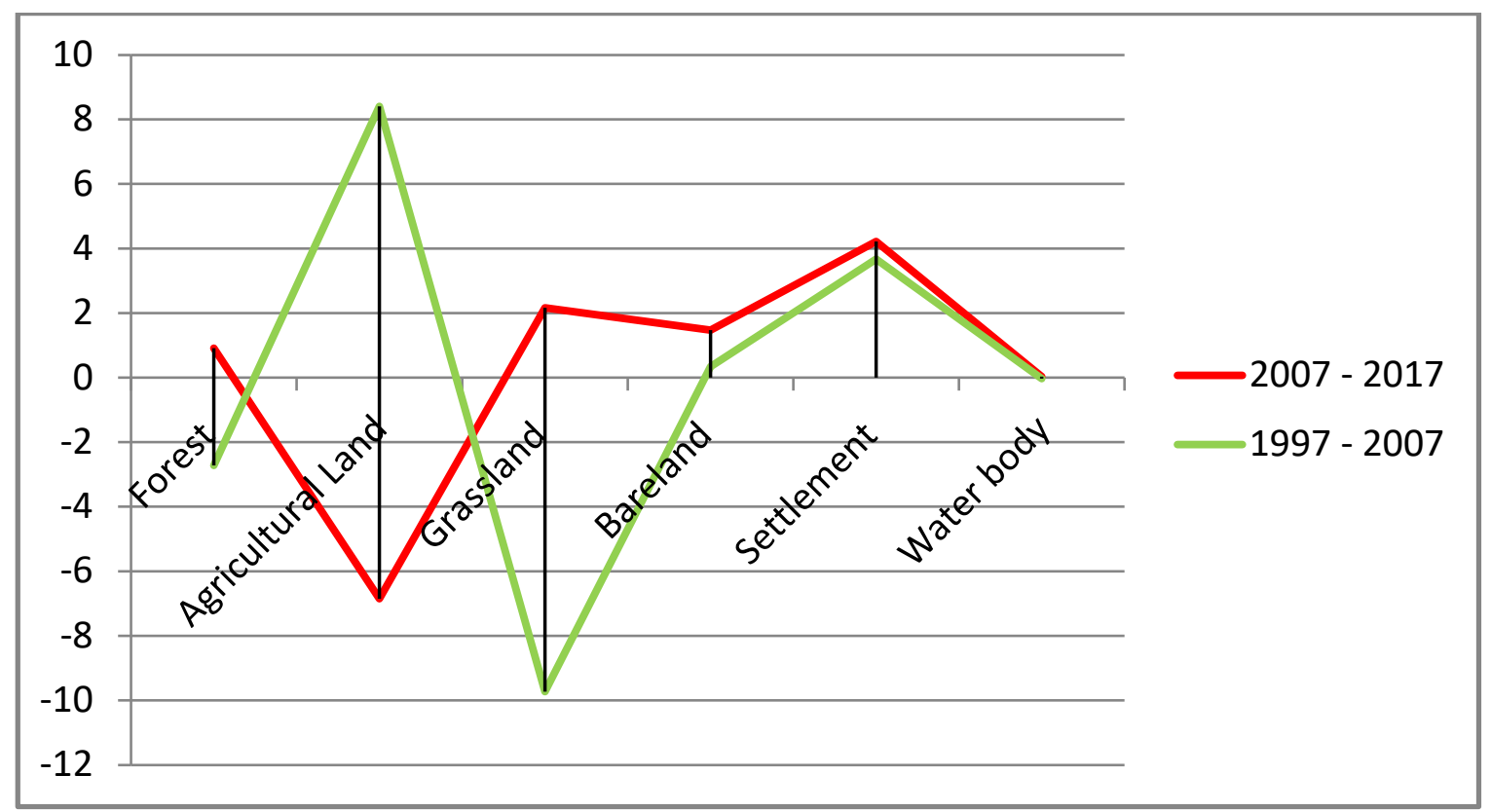

Figure 3: Change in Land Use/Land Cover (\%)

Source: GIS Analysis, 2019

The change in land use/land cover between 2007 and 2017 is presented in Table 3, Figure 2 and Figure 3. The data show the total area covered by each feature in hectares and their respective proportions (in percentage) in 2007 and 2017. The Table also reveals the percentage of change in land cover types that occurred in the area between the given periods. A negative change indicates loss of land cover/land use type. The table revealed that agricultural land has a negative change of $-6.85 \%$, between 2007 and 2017 , while Settlement has a positive change of $4.22 \%$, forest, grassland, bare land and water body have a positive change of $0.91 \%, 2.16 \%, 1,47 \%$ and $0.03 \%$.

It can be inferred that there is a steady increase in settlement expansion in Makurdi between 2007 and 2017 which may not be unconnected with the increase in population, it can also be deduced that there is decrease or loss in agricultural land use in the study area, while there is an increase in settlement within the same period and this may not be unconnected with the settlement expansion within the period (see satellite images for these changes in Figure 4-6)

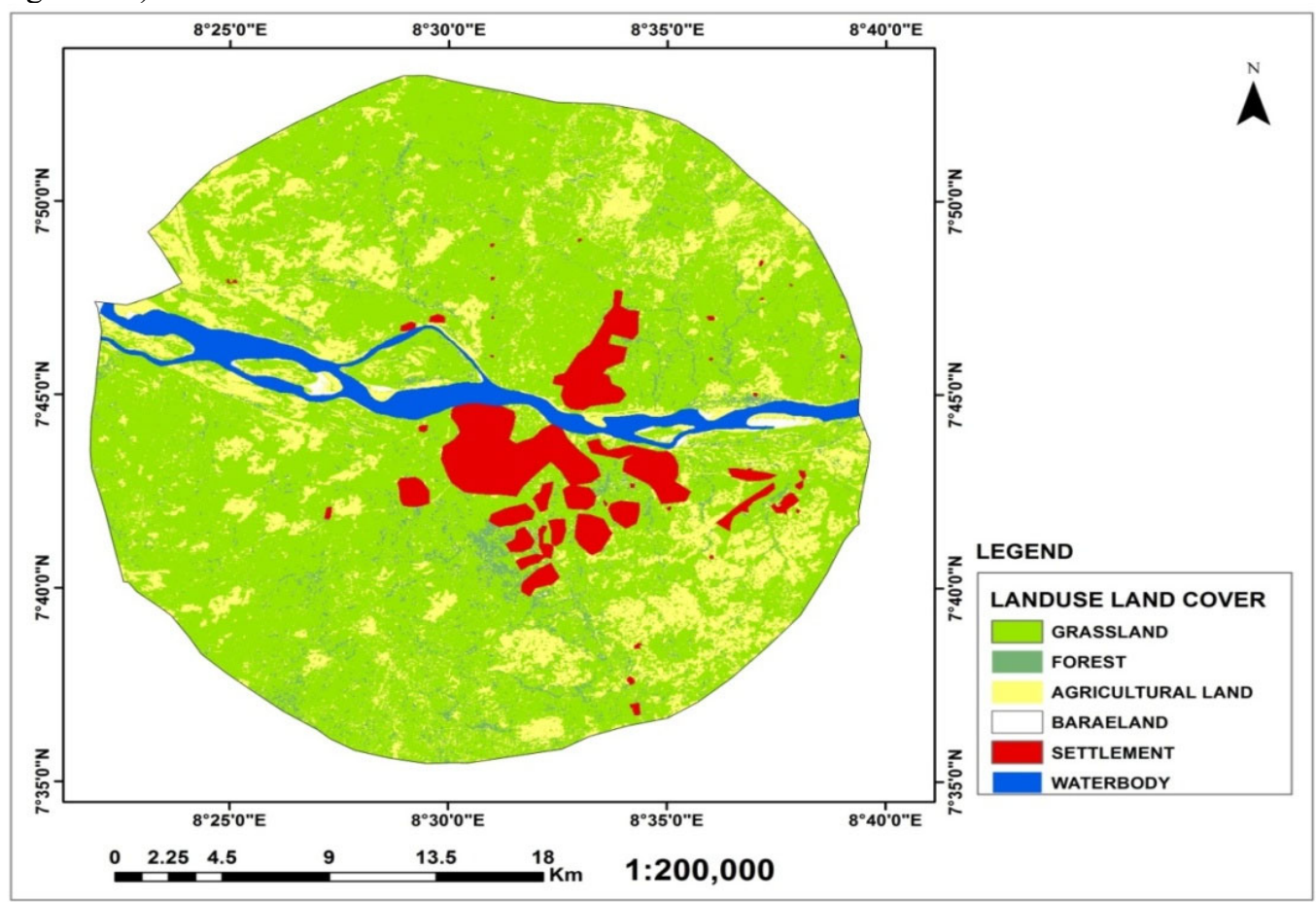

Figure 4: Land use Land cover of the Study Area in 1997.

(Source: Author GIS Analysis, 2019) 


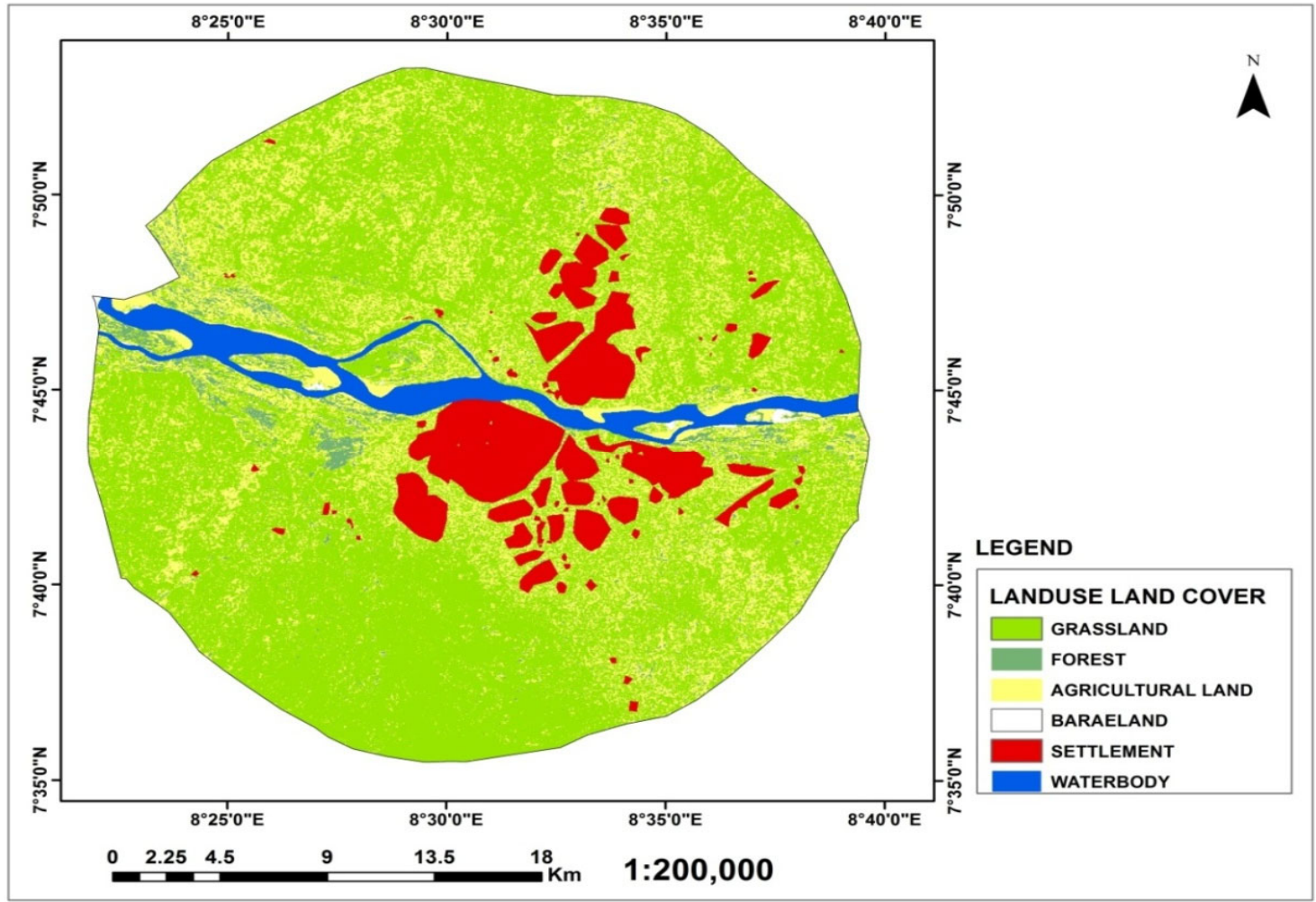

Figure 5: Land use Land cover of the Study Area in 2007 (Source: Author GIS Analysis, 2019)

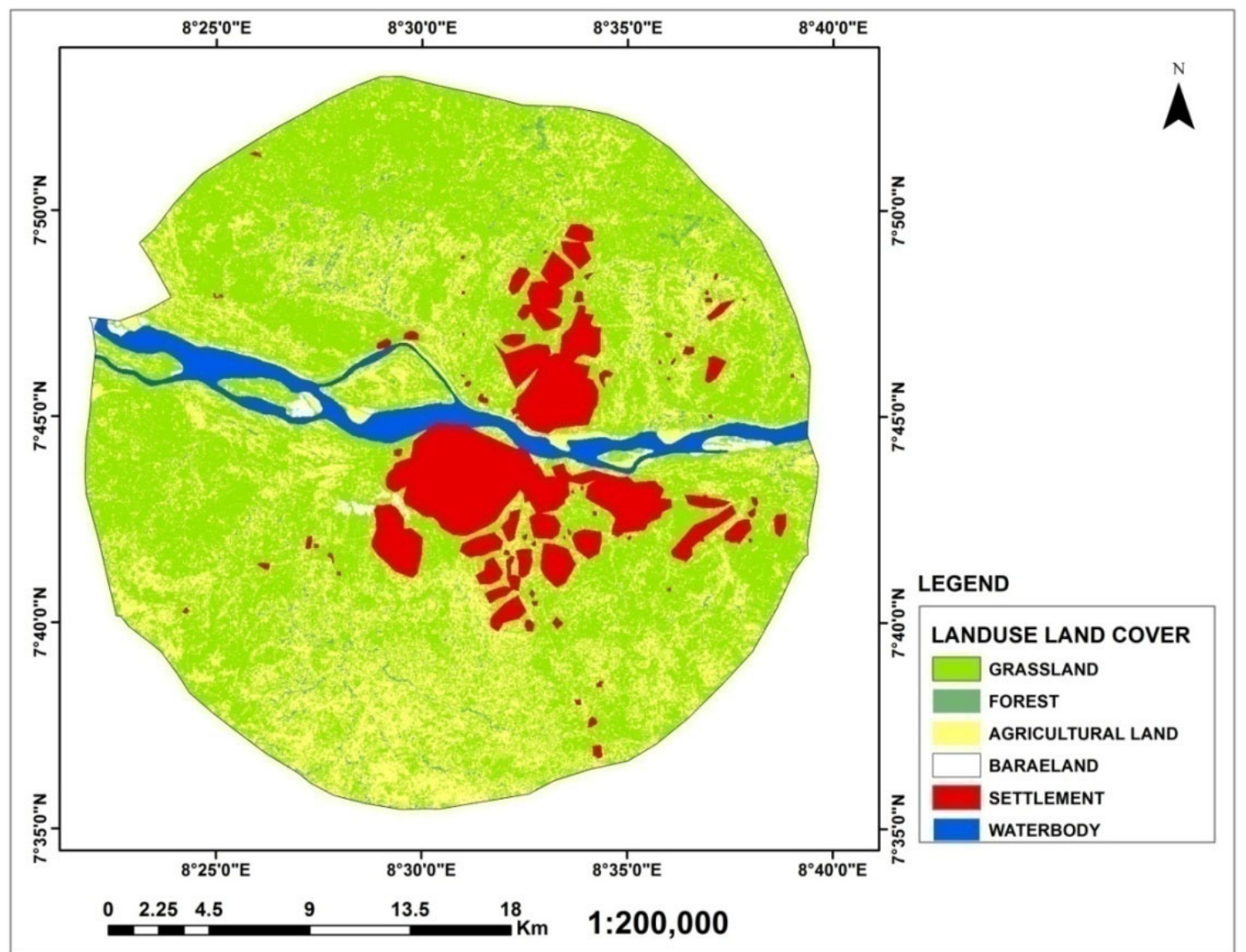

Figure 6: Land use Land cover of the Study Area in 2017

(Source: Author GIS Analysis, 2019) 


\section{Effects of Urbanization on Agricultural land use n Makurdi LGA}

This section focuses on the loss of agricultural land use between 1997 and 2017 concerning urbanization in the study area. Emphases are on how human influence through settlement and other land use affect agricultural land in Makurdi LGA, Benue State.

Table 5: Loss in Agricultural Land Use from 1997-2017

\begin{tabular}{ll}
\hline land use change 1997- 2017 & Area in hectare \\
\hline Agricultural land to Grassland & 47.40 \\
Agricultural land to Forest & 52.90 \\
Agricultural land to Bareland & 44.16 \\
Agricultural land to Settlement & 99.51 \\
Agricultural land to Waterbody & 24.7 \\
\hline
\end{tabular}

(Source: Author GIS Analysis 2019)

Table 5 shows a loss in agricultural land in Makurdi L.G.A between 1997 and 2017, but the focus of the study is how much of agricultural land has been converted to settlement between 1997 and 2017. The Table revealed that $99.51 \mathrm{Ha}$ of agricultural land use have been converted to settlement between 1997 and 2017. The data also show how much other land covers such as grassland, forest and bare land, affect agricultural land use within this period. The conversion of agricultural land to settlement suggests that urbanization has an effect on agricultural land use in the study area. It can therefore be inferred that one of the major effects of urbanization on agricultural land use in Makurdi, Benue State is the conversion of farmland to the built-up area.

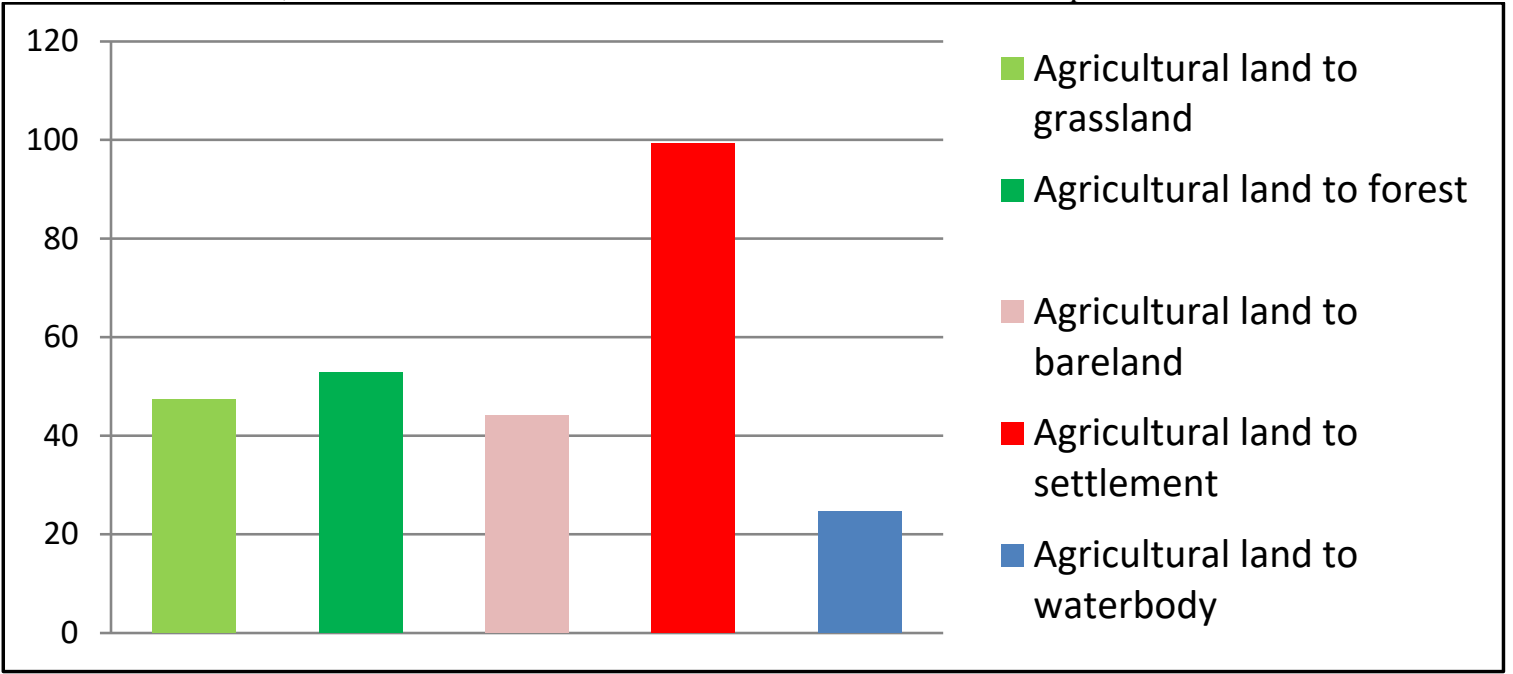

Figure 7: Loss in Agricultural Land from 1997-2017 (Area in hectare)

The foregone results further show that urbanization has caused a substantial reduction in the arable lands in Makurdi LGA and the surrounding communities. This finding supports the assertion of Appiah, Asante and Nketiah, (2019) that agriculture land conversions have occurred in most peri-urban zones across the globe which has reduced croplands over the past two decades. The pressure put on agricultural land by the urbanization process puts peri-urban and rural food production increasingly at risk (Eaton \& Hilhorst, 2003 and FAO, 2000) as well as threat to food security and reduction in the livelihood of those that depend on these farmlands. The socio-economic impact is the loss of livelihood by farmers and people that participate.

\section{Conclusion}

The importance of agriculture to economic development to Nigeria in general and Benue State, in particular, cannot be overemphasized. This study has established that urbanization has significant effects on agricultural land in the area and these effects include decreasing agricultural land, decreasing agricultural activities and a decrease in farm size. Adequate policies must be put in place to curtail the effects of urbanization on agricultural land in the area. The population of Makurdi has grown more than double in twenty years and it is projected to further double that increase in thirty years. Therefore, agriculture competes for land with other urban land uses, which generate higher economic rents. If this growth in population continues unchecked, agricultural land will decrease significantly in the future in the study area. The study, therefore, recommends the following: there should be laws and policies to control population growth in a sustainable manner in urban areas, agricultural intensification should be encouraged so as to boost agricultural productivity in the area and urban agriculture should be encouraged within urbanized areas for sustainable food supply in urban areas. 


\section{References}

Adeboyejo, T. and Abolade, O. (2007), Household Responses to Urban Encroachment on the Rural Hinterland in the Ogbomoso Urban Fringe, Nigeria. http://www.populationenvironmentresearch.org/workshops.jsp\#w2007

Adedeji, Adebayo (1973) Urbanization Challenge in Nigeria: A Race Against Time. In Adedeji, A and Rowland, L (eds) Management Problems of Rapid Urbanization in Nigeria. Ile-ife: University of Ife Press.

Adesina F.A, (2005). Geo-information and Natural Resources Exploitation in Africa; United Nations Economic and Social Council. Paper Delivered in Fourth Meeting of the Committee on Development Information, Addis Ababa on 23-28 April.

Angel, S., Sheppard, S., and Civco, D. (2005). The Dynamics of Global Urban Expansion. Washington, DC: World Bank.

Appiah, D. O. Bugri, J. T. Forkuo, E. K. and Boateng, P. K. (2014). Determinants of Peri- Urbanization and Land Use Change Patterns in Peri-Urban Ghana. Journal of Sustainable Development; Vol. 7, No. 6; 2014 ISSN 1913-9063 E-ISSN 1913-9071 Published by Canadian Center of Science and Education

Appiah, D. O., Asante, F., and Nketiah, B. (2019). Perspective on Agricultural Land Use Conversion and Food Security in Rural Ghana, Science 1, Vol. 14.

Brennan, E M (1999) Population, Urbanization, Environment and Security: A Summary of the Issues, Washington DC, Woodrow Wilson International Center for Scholars Comparative Urban Studies Occasional Papers Series, 22.

Dekolo, S. O and Olayinka, D. N. (2014). Monitoring peri-urban land use change with multi temporal Landsat imagery. Retrieved from https://www.researchgate.net/publication/265476498 accessed on 13 August, 2017.

Denga, D. I. (1995). Tiv People: origins, Migrations and Social Set-Up, Benue State, The Land of Great Potentials: A Compendium, edited by Denga, D. I, Rapid Educational Publishers ltd, Nigeria.

Eaton, D., \& Hilhorst, T. (2003). Opportunities for Managing Solid Waste Flows In The Periurban Interface Of Bamako And Ouagadougou. Environment and Urbanization 15(1): 53- 64.

FAO, (2000). Feeding Asian Cities. Proceedings of the regional seminar organized by: The Regional Network of Local Authorities for the Management of Human Settlements (CityNet) and the Association of Food Marketing Agencies in Asia and the Pacific (AFMA), with the technical support of the Food and Agriculture Organization of the United Nations (FAO) Bangkok, Thailand November 27-30, 2000

Fellmann, J., Getis, A. and Getis, J. (1996). Human Geography: Landscape of Human Activities, USA, Times Mirror Higher Education Group, Inc.

Kwasi N. G. (2004). Urbanization Process - Environmental and Health Effects in Africa. Population Environment Research Network (PERN) Cyber seminar, Urban Expansion: The Environmental and Health Dimension.

Lambin, E. F., Geist, H. J. and Lepers, E. (2003). Dynamics of Land-use and Land-cover changing Tropical Regions, Annual Review Environmental Resources, 28.

Mandere, M. N., Ness, B. and Anderberg, S. (2010). Peri-urban development, livelihood change and household income: A case study of Peri-urban Nyahururu, Kenya. Journal of Agricultural Extension and Rural Development, 2(5), 73-83.

Mugish, J. and Nyandwi, E. (2015). Kigali City Peri-Urbanization and its Implications on Peri-Urban Land Use Dynamics: Cases of Muyumbu and Nyakaliro. GeoTechRwanda 2015 - Kigali, 18- 20 November 2015

Naab, F. Z., Dinye, R. D. and Kasanga, R. K. (2013). Urbanisation and its Impact on Agricultural Lands in Growing Cities in Developing Countries: A Case Study of Tamale in Ghana. Modern Social Science Journal, 2, No. 2, 256-287.

NITP. (2014). The State of Urban and Regional Planning in Nigeria. NITP,

Oguntoyinbo, J.S. (1981) Aspect of Urban Microclimate. The Case of Ibadan. In: Sada, P.O. and Oguntoyinbo, J.S., Eds., Urbanization Processes and Problem in Nigeria, Ibadan University Press, Ibadan, 137-139.

Olima, W. H. A., (2003). Urbanisation and Housing Challenges. Cities in Africa Conference. Rapporteur's report

Oueslati, W., Sulenie, J. and Wu, J. (2014). Urbanization and Agricultural Structural Adjustments: Some Lessons From European Cities, Working Paper.

Oyesiku, K and Alade, W. (2010). Historical Development of Urban and Regional Planning in Nigeria State of Planning Report, Nigerian Institute of Town Planners

Sati, V. P., Deng, W., Zhang, S., Wan, J. and Song, X. (2017). Urbanization and Its Impact on Rural Livelihood: A Study of Xichang City Administration, Sichuan Province, China, Chinese Journal of Urban and Environmental Studies, Vol. 5, No. 4.

Shabu T., (2010). The Relationship between Urbanization and Economic Development, International Journal of Economic Development and Investment, Vol. 1, No. 2 \& 3.

Sjoberg, A. (1960) The Pre-industrial City: Past present and future Free Press, New York

Zasada, I. (2011). Multi-functional peri-urban agriculture-A review of societal demands and the provision of goods and services by farming. Land Use Policy 28, 639-648. 